THE TYNDALE HISTORICAL THEOLOGY LECTURE, 1981

\title{
LUTHER AND THE WITTENBERG DISPUTATIONS 1535-36
}

By James Atkinson

As a technique both for making clear the evangelical theology, as well as for answering its opponents, the disputation played a decisive role in the Reformation. One has only to consider the significance of the Disputation against the Scholastic Theology (1517) which started off the Reformation; ${ }^{1}$ the Disputation against Indulgences and the Resolutions which explained the debate $(1517) i^{2}$ the Disputation at Heidelberg (1518) when Luther explained his evangelical theology to his fellow monks in an atmosphere free of controversy; ${ }^{3}$ and the Disputation of Leipzig (1519) when Luther faced the Catholic attack on his theology delivered by John Eck." Luther was later to re-organise the ordering of disputations at the University of Wittenberg in 1533, for he criticised the state they had fallen into, on the grounds that the disputants engaged in logical word-play, and discussed questions to which nobody wanted answers. Luther argued that disputations should be on the live issues of the day as a method to elicit truth, and that such disputations should be an important factor in a student's training. It was only two years later that Luther set up the disputations of 1535-36, when the English theologians went to Wittenberg to effect two things, first the approval of the Wittenberg theologians for the divorce of Henry VIII of Catherine of Aragon, and secondly to see whether there could be a theological rapprochement between England and Saxony. These disputations actually tell England what the Reformation is about, and what England must do to effect it.

Before considering the actual disputations it is necessary to look at the events which preceded them to

1. D. Martin Luthers Werke. Kritische Gesamtausgabe (Weimar, 1883-) (cited as WA) I, 221-228. See Library of Christian Classics. Volume XVI. Luther: Early Theological Works (ed. and trans. by J. Atkinson; London: SCM, 1962) 251-273,

2. WA. I. 233-238; 525-628.

3. WA. I. 350-365; LCC, Vol. 16, 274-307.

4. WA. II. 391-435. 
give them their context. First, there are the theological issues: namely, Luther's De Captivitate (1520) which occasioned Henry's attack on Luther's theology in his Assertio (1521) to which Luther replied in his Contra Henricum (1522). Secondly, there is the matter of the king's divorce, handled here briefly as of no theological significance.

\section{Luther's De Captivitate (1520), Henry's Assertio (1521), Luther's Contra Henricum (1522).}

Within about a year of the posting of the XCV Theses against indulgences (1517), Luther's works had been exported to England. 5 That these books had attracted the attention of the government may be inferred from the statement of Erasmus, that but for his intervention, they would have been burned. ${ }^{6}$ It may be presumed that it was from Erasmus that Henry VIII gained his first impression of Luther. In May $1519^{7}$ Erasmus wrote to Wolsey, gently excusing Luther, though making it clear that he was no supporter of the new movement. Nevertheless, it is to the credit of Erasmus that during the next two years he did everything in his power to heal the schism and to secure a fair hearing for Luther. ${ }^{8}$ By personal interview, by pamphleteering (mainly anonymous), and by letters to influential men, he urged the advisability of using argument rather than force in seeking to silence Luther. He requested that Luther be given a trial before a body of learned and impartial judges, and that these judges should be appointed by the kings of Hungary and England. ${ }^{9}$ Erasmus actually took the trouble of interviewing the envoys of Hungary

5. Froben to Luther $14 \mathrm{Feb} 1519$ (D. Martin Luthers Werke. Briefwechsel (Weimar, 1930- ) (cited as W. $B r$.$) I. 33lff, 14 \mathrm{Feb}$. 1519). See also the day book of the oxford bookseller, John Dorne, in which is linted a number of Luther's works he is then selling, 1520 (Oxford Historical Society, Collectanea $i$ (1885) 164).

6. Erasmus to Oecolampadius 15 May 1520 (Erasmi Opera 1701-06, III. 509).

7. Ibid. No. 317. The letter is there dated 1518, but later research has amended it to 1519.

8. See, e.g. P. Kalkoff, Die Vermittlungspolitik des Erasmus (Archiv für Reformationsgeschichte) (Leipzig, 1903-04) 1-83.

9. Ibid. $17 \mathrm{ff}$. 
in the Netherlands and Henry himself in July 1520 when Henry crossed the channel for the coronation of Charles $\mathrm{V}$ at Aachen. 10

It is quite certain that a major reason for Henry to take so decided a part against Luther within a year of discussing the matter with the gentle and tolerant Erasmus was that Wolsey now had Henry's ear. It was Wolsey who persuaded Henry VIII to write against luther, for he stated that himself in his congratulatory address to the king. Wolsey's ambitions for the papacy gave him a strong bias against Luther's theology. When letters came from Leo $\mathrm{x}^{11}$ ordering Wolsey to burn the books of the obnoxious friar the command was obeyed with alacrity and diligence.

Meanwhile, the Diet of Worms was opened, on 28th January 1521. A topic of general discussion was whether Luther, a person under papal interdict, could with propriety even be allowed to appear in person, much less argue any case. Cuthbert Tunstall, Henry VIII's ambassador to the court of Charles $v$, in a letter to Cardinal Wolsey written from Worms on the very next day, described how Luther and his fellow professors at Wittenberg had publicly burnt the Papal Bull and with it the Canon Law. In the same letter he referred to the dangerous theology contained in the De Captivitate Babylonica, and actually said, 'I pray God keep that book out of England'.12 It is difficult to understand why in his great concern with Luther he actually left Worms on llth April, five days before Luther's appearance there, and did not deign at least to meet the man. On 16th April, 1521, the very day of Luther's appearance in Worms, Secretary Pace wrote to Wolsey that he had found the king readirg a new book of Luther. This book was the De Captivitate, a book, Pace goes on to say, which Henry condemned, and on being shown the papal condemnation of the same, Henry said that it was his intention to write a refutation of the book himself: he would finish the writing

10. Myconius to Laurinus 1 Feb. 1523 (Le Clerc. No. 650).

11. Letters and Papers of Henry VIII, III.i. No. 1234 (17 Apr. 152l) (cited as L. \& P.).

12. H. Ellis, Original Letters. 'ihird Series I (1846) 239f; L. \& P. III.i. ccccix. 
of it in a few days, and have it distributed throughout Europe. 13

It is known that already as early as 1517 Henry VIII had been at work on a theological treatise intended to refute the XCV Theses against indulgences, and it is a fair assumption that Henry made use of these earlier notes and sketches when he actually came to write his Assertio septem Sacramentorum adversus Martinum Lutherum, a surmise supported by the fact that in the actual text of the Assertio Henry considers indulgences at some length, yet it is a subject that hardly gets a reference in the De Captivitate at all, and a subject theologically dead when Henry wrote his Assertio. Henry certainly wrote to the Pope, 2lst May 1521, to the effect that it had long been his intention to write against Luther's heresy, and to dedicate to him 'the first offerings of his intellect and his little erudition', by means of which 'to testify his zeal for the faith by his writings, that all might see he was ready to defend the church, not only with his arms, but with the resources of his mind'. 14

Shortly after receiving Tunstall's urgent request to allow none of Luther's books into England, Wolsey received a further letter from Rome which, while approving of Wolsey's prevention of the importation of Luther's books into England, went on to express the opinion that since so many had got into England anyway, a far better course would be to consign to the flames those books that were already there. ${ }^{15}$ Archbishop Warham, too, expressed great concern to Wolsey that now the universities of oxford and Cambridge were 'infected with the heresies of Luther', and that Wolsey himself should deal with these 'captains of Lutheranism'.16

On Sunday, 12th May 1521, the king, Wolsey, the papal nuncio, the Archbishop of Canterbury, the foreign ambassadors, the Bishop of London and others trooped along to St. Paul's Cathedral to see Luther's books committed to the flames. John Fisher, the Bishop of Rochester, preached a long and solemn sermon, commended the king and Wolsey, 'reprobating the friar Martin',

13. L. \& P. III.i. 1233 (16 Apr. 1521).

14. L. \& P. III.i. 1297 (21 May 1521).

15. L. \& P. III.i. 1210 (Feb. 1521?).

16. H. Ellis, Original Letters. Third Series I (1846) $239 f$. 
and upheld the authority of the pope. Wolsey published the papal brief, and announced Henry's forthcoming book. 17 on 30th May the king wrote to the emperor, who had just heard Luther at Worms (17-18 April), 'begging, admonishing, and conjuring his majesty to root up the poisonous weed of heresy, and extirpate both Luther and his pestilential books with fire and sword for the honour of holy church and the papal see'. ${ }^{18}$ Henry VIII issued repeated proclamations for the destruction of these books, and there is considerable evidence in the concern expressed by Cuthbert Tunstall as Bishop of London and by Thomas More that the influence of Luther had gone far beyond the university cities.

On 2nd October, Dr. Clerk, the ambassador in Rome, presented to the pope a sumptuous copy of Henry's book, beautifully bound in gold, and in an unctuous speech, expressed detestation of Luther, lauded Henry to the heights, 19 and secured for his royal master the long coveted title Fidei Defensor. The bull was speedily sent to Wolsey, and the title ceremoniously conferred on Henry in spectacular pomp at a great celebration at Greenwich.

In the book Henry had argued that Luther was a vile heretic whose false and frivolous teaching was the product of a mind utterly divorced from God: it was a scurrilous, abusive and offensive book. Brewer's opinion is balanced and sound:

It produced without novelty or energy the old commonplaces of authority, tradition and general consent. The cardinal principles of Luther's teaching the king did not understand and did not therefore attempt to refute. Contented to point out the mere straws on the surface of the current ... reproduces without force, originality or feeling the weary topics he had picked up, without much thought or research, from the theological manuals of the day. 20

17. L. \& P. III.i. 1274 .

18. Quoted by Preserved Smith (English Historical Review, No. C, Oct. 1910, 658).

19. L. \& P. III.i. 1656.

20. L. \& P. III.i. cccexxvii. 
Who actually wrote the book is another question. At the time few believed that it was Henry's own effort unaided, and most scholars trace another hand, that of Thomas More, or Wolsey, or John Fisher, or Richard Pace. Even Erasmus was suspected, though he always averred it was largely Henry's. Luther always thought that it was the work of Edward Lee.

Henry had assembled (assuming Henry's responsibility for the book) a number of arguments, but Luther had long since thought his way through and beyond such elementary, traditional statements. The significance of the book is less its contents, much more the scathing and vitriolic attack Luther launched against Henry. The book lent excessively heavy support to the papacy, so heavy indeed as to alarm More himself (no mean papist), who took it upon himself to warn Henry he may regret that statement one day, a warning that was prophetically true. ${ }^{21}$ In addition to its uncompromising loyalty to the papacy the book gives an unwavering assertion of the seven sacraments as against Luther's argument of three only, as being those established by Christ while the others, though of a sacramental significance, had simply grown up in the Church. Translations of Henry's book were made immediately by Luther's old Catholic controversialists, Emser and Murner, which translations caused great excitement in Europe.

Luther wrote a spirited answer, Contra Henricum Regem Angliae in Latin but also produced a German version (not a translation). Its excessive rudeness astonished the king, and indeed all Christendom, including many of Luther's friends, but the prolific insults and outbursts hurled against Henry should not obscure the fact that the reply produced a competent rejection of the king's commonplaces. Luther was incensed that so shallow and ill-informed an attack should emanate from such a distinguished quarter. Luther felt that Henry, as all his adversaries (he was later to make the honourable exception of Erasmus in 1515), had failed to understand, or chosen to ignore, the fundamental distinction made by him between sound learning based on the Scriptures on the one hand, and the discredited apparatus of tradition, customs, decretals, and scholastic decisions or opinions on the other.

21. W. Roper, Lyfe of Sir Thomas More (Early English Text Society, 1935) 66. 
Henry, of course, was no match for Luther on the theological field, but he was given a golden opportunity to humiliate him later. In 1525, King Christian II of Denmark persuaded Luther that to his certain knowledge Henry VIII was turning favourable to the evangelical faith, and that if Luther were to offer an appropriate apology, the way would be open for Henry to find new relations with the Lutherans. Against his own better judgment, and pressed by advisers, Luther obliged with a ghastly, obsequious, monkish apology, ${ }^{22}$ not strictly an apology, but a diplomatic offer of one, and had the want of tact to say that he was quite sure Henry had never written it himself, and actually referred to Wolsey as 'that monster detested of God and man'. Luther was acting on two assumptions, both false. He was wrongly informed by Christian II, a time-server and fisher in troubled waters; he was also wrongly informed that Wolsey had fallen from grace. After about a year (Aug. 1526) Henry wrote a still more fierce reply. He published Luther's foolish offer of an apology, and taunts him with having caused the Peasants' War of 1525, and with having violated a nun: he further discussed two theological points of Luther, the error of justification by faith alone and the denial of free-will. This was seized on by Luther's old enemy Emser, who in 1527 translated the pamphlet and turned an offer of an apology into a recantation. This stirred Luther into a reply, early in $1527 .{ }^{23}$ Henry's only reply was to buffoon Luther and his wife on the stage at one of his many revels and carnivals, loth November 1527.24

To return to Luther's reply to Henry's attack: Henry made no reply, refutations came from John Fisher and Sir Thomas More. The bishop wrote a calm but diffusive answer, very thin indeed on the theological side. More wrote an abusive, vulgar, controversial reply, under the pseudonym of G. Rossaeus. ${ }^{25}$ Henry's Assertio contained a great deal of invective, but the abusive tone of More's reply is so dominant and gross as to be revolting. Erasmus was horrified at the book, but never for a moment associated it with his friend More, the

22. WA. III. 562f. (I Sept. 1525).

23. WA. xxiii. 17 .

24. L. \& P. IV.ii. 3564.

25. G. Rossaeus, Eruditissimi viri G. Rossi opus ... quo ... refollit ... Lutheri calumnias (1523). 
kindly, saintly More. ${ }^{26}$ Luther did not trouble himself to reply either to Fisher's or More's book. It is interesting to reflect on the fact that in 1534 Henry actually accused More of instigating the book which had 'put a sword in the Pope's handes to fight against him selfe', 27 a fact which More had foreseen for he had forewarned Henry at the time.

\section{The Divorce and Luther}

The next phase in the relationship between Henry VIII and Luther was the matter of the divorce (correctly speaking annulment) between Henry VIII and Catherine of Aragon. A full account of Henry's attempts to obtain a decree of nullity in respect of his marriage with Catherine is not necessary here, ${ }^{28}$ but a brief account of the events which led to the involvement of Luther is attempted.

Since only one of Catherine's children to survive infancy was a daughter, Mary (later Queen Mary), Henry became increasingly concerned about the Tudor succession now that Catherine was past child-bearing. At this time he also conceived an infatuation for Anne Boleyn, who refused to be his mistress, but would consent to be his queen. Henry contrived the argument that Catherine had never been his true wife, for she had been his brother's wife, and that the papal dispensation to allow the marriage had been unlawful. He sought unsuccessfully to force the Pope to annul the earlier dispensation, which would mean that he was free to marry Anne. He then excluded the Papacy from all jurisdiction in England, fined the clergy for supporting the Pope, summoned himself and Catherine to an English court (Catherine proved contumacious), and finally secured annulment by an English court. Later his marriage to Anne was pronounced valid.

In the earlier stages when he was seeking to force the hand of the Pope, he had (on the advice of Cranmer)

26. Erasmus, Opera (1703) X. 1652.

27. Roper, More, 67f.

28. A reliable summary may be found in E. Doernberg, Henry VIII and Luther (London, 1961) $63 \mathrm{ff.}$ 
sought to find favourable opinions on the divorce from seats of learning in Europe outside the jurisdiction of Charles $v$, a move which very cleverly set aside the Pope as a final authority in this matter. It was at this point that Luther became involved.

That Henry continued to approach Wittenberg after his clashes with Luther in 1521 and 1525 must indicate that the divorce meant more to Henry than is generally presumed. In answer to Luther's offer of an apology in 1526 Henry had referred sarcastically to the theological refugees who had fled the realm and told Luther he could have any others if any were left. In 1531 the idea occurred to Henry that he could use these refugees to influence Luther. The lot fell upon Robert Barnes who was invited to return to England.

Barnes, who had studied at Louvain, was thereafter prior of the Augustinians at Cambridge. He had been deeply devoted to Luther and his theology, and had got himself into trouble for preaching at st. Edmunds, Cambridge, on Christmas Eve 1525, what was virtually a sermon from Luther. He was charged before the Vice-Chancellor, and again before Wolsey, on twenty-five points of heresy. After a long trial of three days he recanted, 1526, but was actually imprisoned in London and not allowed to return to Cambridge. Eventually he fled the country in 1528, by feigning drowning. He escaped to Antwerp and then went on to Wittenberg, where he enrolled and took his doctorate, living as Luther's guest and also in Bugenhagen's house.

When Barnes was invited back, a great deal had happened in England. As just described, Henry had succeeded in marrying Anne Boleyn, established himself as head of the Church, brought the clergy to heel, and even fined them all. Things were in a state of flux. Barnes had been secretly invited, not by Henry but by Cromwell. Not even More knew of this, and when he learnt of Barnes' return, sought to arrest him as a lapsed heretic. Through a third party Henry gave Barnes a copy of the verdicts on the marriage made by the various universities, with the request that Luther's opinion on these judgments be solicited. Barnes returned to Wittenberg at once. Simon Grynaeus, the distinguished German humanist of Basel, was asked to solicit the opinions of Oecolampadius, Zwingli, Bucer and others: Cranmer consulted his uncle Osiander, the learned old Testament 
scholar, on the text in Deuteronomy 25:5f and Leviticus 15:16. Osiander judged that the papal dispensation of 1503 had been unlawful and unscriptural. Barnes knew Luther's answer before he gave it, and when it was given on 5th September 1531, it was written with great care and detail, a fine, disinterested, painstaking and impartial judgment. Luther approved the Louvain judgment, that Henry, even if there were any fault in the 1503 dispensation, could not disown his true and lawful wife Catherine and thereby taint and hurt both daughter and mother. He discusses with great care the relevant passages of Deuteronomy and Leviticus. He suggests that his verdict will not be welcome and may not help the issue, and invites Barnes to use it according to his own discretion. ${ }^{29}$

Barnes returned to England immediately with this answer, which did not please Henry. Yet Henry persisted. The very day after Barnes' arrival Paget was dispatched to open new negotiations with the Protestant princes, and there followed further attempts in 1532, 1534, 1536-39. But from this date, 1532, the divorce ceased to be the sole object of Henry's negotiations with the Lutherans, and how those relations passed to their final phase we shall see in the next section.

\section{New Approaches to Wittenberg}

Three ideas seemed to be in Henry's mind when, on receipt of Barnes' unfavourable reply from Wittenberg, ${ }^{30}$ he dispatched Paget to the Protestant princes of Germany. ${ }^{31}$ First, his resolute intention to secure the Lutherans' approval of the divorce, secondly his desire to join the Schmalkald League of Protestant princes, and lastly, owing to the development of the Henrician reformation (if one may use that word of Henry's 'management' of the Church), the necessity of taking a fresh look at the Lutheran theology. Henry was purely opportunist in any situation: he was Lutheran when dissolving the monasteries, but Catholic in celibacy. Celibacy had no political or financial significance; the monasteries, much wealth.

29. W. Br. VI. 175ff (3 Sept. 1531).

30. L. \& P. V. 593, 737 .

31. I. \& P. V. 1531. 
The League of Schmalkald came into being in the course of defensive discussions among the German protestant princes relating to the jurisdiction of the imperial courts which continually harassed them. The Catholic Bavarian princes were objecting to Archduke Ferdinand's election as King of Rome and had actually approached Philip of Hesse. Philip was concerned about the dynastic ambitions of the Hapsburgs and wanted support from Henry VIII. Towards the end of the year 1531, Philip sent his emissary licentiat Nicolaus Meyer to seek a better understanding with Henry; Henry had already dispatched Paget. This meant that in 1532 Henry had both Cranmer and Paget in Southern Germany. In May of that year the League had made a treaty with France, and strangely enough, the League became of interest to the Pope whose friendship with Charles had come to an end. The Emperor was urging the Pope to call a council. These political complications, coupled with the constant Turkish threat, lead to consultations in Rome in 1531 and 1532 as to whether it would not be advisable to make a few concessions to the Lutherans to win their cooperation. Serious negotiations ensued between Cardinal Bellay and the Lutherans. At the request of the Bishop of Paris, Melanchthon drew up articles for discussion. These contained formidable concessions on the part of the Lutherans and interested the Catholics. Melanchthon was invited to paris.

The endless diplomatic intrigues and entanglements of the period may only be indicated in this brief essay, but they are significant and should not be omitted, for there was more to the negotiations than theological concerns. Charles had made treaties with the Protestants in 1532 at Regensburg and Nuremberg; the second son of Francis had married Clement VII's niece; the Pope and Francis had come to an agreement in Marseilles in 1533. As for Henry, his moves were similarly complicated, even devious. Henry had been giving assistance to Jürgen Wollenwever who had established a powerful democratic regime at lübeck. This was weakening the Hanse and causing troubles in Denmark; Henry was actually offered the crown of Denmark at one stage. Henry was watching closely with a view to strengthening his own position. He realised that if Rome and Wittenberg were to be reconciled, he would be left alone in schism. Threatened with such isolation he wanted alliance with Francis, failing that, even with the Lutherans. Relations were not good with Francis, and when he learned that Melanchthon had been 
invited to Paris, Henry was immediately interested in the Lutherans and invited Melanchthon to England, not Luther, be it noted, who would have cut Henry down to size, but the gentle, respectful, cooperative Melanchthon.

In July 1533 Stephen Vaughan, a friend of Cromwell, was sent to Germany to make alliances with various Lutheran princes, but so vague was his commission that he returned fruitless. 32 It was not till the summer of 1535 when the three theologians Dr. Barnes, Bishop Foxe and Archdeacon Heath came to Germany that Luther grew interested and involved. Between 1531 and 1535 Luther would not concern himself with the affairs of Henry VIII who had kept all the discussions on a political level, for Luther had no interest in politics. Following the invitation to Melanchthon to go to Paris, Henry had kindled some interest in the Lutherans and had actually sent Melanchthon, by the hand of Barnes, an invitation to London with a gift of 500 florins ${ }^{33}$ (together with a gift for Luther of 50 florins! One can almost hear Luther tease Melanchthon!). Melanchthon had been very bitter when John Frederick withheld his permission for Melanchthon to go to Paris on the grounds that he could not trust Melanchthon who he feared would go far beyond Luther's mind to conciliate the Catholics. ${ }^{34}$ Yet even Luther went so far as to say that perhaps God was moving in the matter, and that the overtures of the King of England should not be summarily refused ${ }^{35}$ and Melanchthon allowed to go to England, 36 but when news came of the execution of Fisher (22nd June 1535), and of More (6th July 1535), the Lutherans, though they had no reason to respect the memory of either man, were appalled, and held their distance even with their true friend, Robert Barnes. As late as October 1539 we find John Frederick refusing to grant Melanchthon a travel permit to Britain, though this time Melanchthon was much relieved.

32. State Papers. Henry VIII. VII. 511, 517-18.

33. E. Kroker, Luther's Tischreden (Leipzig, 1903) no. 100, and Corpus Reformatorum ii. 995.

34. G. Mentz, Johann Friedrich der Grossmütige (1903) III, $441 f$.

35. W. Br. VII. $266 f$ (12 Sept. 1535).

36. Luther to Brück 12 Sept. 1535 (W. Br. VII. 267ff and the Beilage attached). 


\section{The Disputations}

At the time when Henry was contriving to bring Melanchthon to England he was also preparing for the most important mission he was to send to the League of Schmalkald. Barnes was sent first to prepare the way, and it is interesting to note that it was the Wittenberg theologians, Luther, Melanchthon, Jonas, Bugenhagen and Cruciger to whom John Frederick issued his instructions. The primary aim of the mission- was to cause the Protestant princes to issue a formal petition to Henry to join them, to give the impression that it was not the King seeking to join but the League which was inviting him.

On 28th November 1535 Foxe and Heath arrived at Erfurt with an impressive array of servants and horses. On 9th December John Frederick received them at Weimar from where they proceeded together to Schmalkalden. On 15th December the delegates met Brück and Burchardt, and on 24th December Foxe addressed the Estates when he delivered a long speech in which he stressed the Protestant intentions of the king and requested further opportunities of discussing theological matters with the Lutheran theologians in order to create a common front for the council. All this was very agreeable to the princes assembled. John Frederick stressed that it would be expected of Henry that he promote the Gospel and the Augsburg Confession before a general council. The petition was signed and the Articles presented on Christmas Day 1535. It was from this document that the Wittenberg Articles (1536) emerged. ${ }^{37}$ When Henry's reply arrived in Wittenberg on 12th March 1536, it showed that he demurred, stating that he himself was learned and he had many learned men in his kingdom, well able to take care of theological concerns. ${ }^{38}$ Henry was clearly unhappy about too close a theological rapprochement.

37. These Articles were not published in England, though the participants must have had copies. They were briefly referred to by Seckendorf, but it was the researches of Georg Mentz in the Weimar archives which eventually produced the text (Die Wittenberger Artikel von 1536, Leipzig 1905).

38. L. \& P. IX. 1016 . 
This did not affect very much the discussions at Schmalkalden, the main concerns of which were political and military, but Foxe's speech on that occasion is important, for it was precisely theological matters which luther took up in Wittenberg when he set up a series of disputations central to the evangelical faith, disputations which one or more of the Englishmen attended and participated in. The political and military decisions came to nothing, and need not be discussed here, but the theological matters will come up again when we examine the disputations. Henry, of course, was offended at the sincerity and earnestness of the Lutherans. He had imagined himself not as a mere member of this League but as "Defender" of the Protestant League. The Lutherans, none more clearly than Luther, knew that Henry had no religion in him at all, and that he intended to use the Lutherans as he had used everybody else, even wife or chancellor of the realm, and to dispose of them when he had no further use for them. That is why the negotiations dragged on until 1540, negotiations which, as Luther said, could have been settled in the time taken to eat a sausage. War es alles mit einer Brat-wurst versiegelt. ${ }^{39}$

From Schmalkalden the English ambassadors travelled to Wittenberg where they arrived on New Year's Day, 1536. Luther expected a brief conference, but it went on for three months, and on 25th January Luther was already exasperated at the waste of time and money, particularly when they were getting nowhere. He said that he had settled bigger things in a month while these people had not settled one point (referring to the divorce) in twelve years. 40 When he was told that all the judges of the English realm were about to issue their verdict, Luther said that his reply to such games was what he says to the goose, Booh! He later said, when queen Catherine died on 9th January 1536, that the only people on her side were the Wittenberg theologians: the Lutherans would not budge from the plain truth, that Catherine was Henry's lawful wedded wife; and that Anne Boleyn was no more than Henry's mistress. After the

\footnotetext{
39. W. Br. VIII. 578.16 (23 oct. 1539). (Luther's comment was a colloquialism meaning the matter is not to be taken seriously.)

40. W. Br. VII. $353 f$ (25 Jan. 1536).
} 
return of the English embassage the Wittenbergers were aghast to learn that Henry had had her beheaded (19th May 1536). ${ }^{4}$

If the divorce question was simple, there was much more to the theological discussions. The English concentrated on three points on which they demanded concessions from the Lutherans: communion under one kind, the private Mass, and the celibacy of priests. The Lutherans showed little interest with such peripheral matters and were concerned essentially with basic evangelical doctrine. The nature of these concerns is adumbrated in the disputations which Luther arranged for the delegates. The importance of these lies not only in their heavy theological content but in the fact that the theses were compiled by Luther himself, and as Dean of the Faculty, he actually ordered all the professors to be present and to take part. ${ }^{42}$ Luther himself chaired the proceedings.

The subject matter of these disputations has yet to be discussed in full, ${ }^{43}$ but the titles are sufficient indication of the themes: De fide. 71 Theses. ${ }^{44}$ 11th September 1535. De lege. 87 Theses. ${ }^{45}$ Same date. Included are a number of counter-theses, as well as the Promotionsrede by Luther himself. The overall theme is the praecipuus locus, justification by faith alone (the articulus stantis et cadentis ecclesiae), the key doctrine which the Catholics (and in this context we are referring to Henry VIII and the then English Church separated though it was from Rome) could not bring themselves to accept. Related to this theme of justification was the disputation on Daniel 4:24 held on l6th October $1535^{46}$ on the advice given by Daniel when he interpreted the dream of Nebuchadnezzar ('... break off thy sins by righteousness, and thine iniquities by showing mercy to the poor'). To this whole group of disputations was related the quaestio on 1 Corinthians 13:2,13. The texts from Daniel and 1 Corinthians

41. W. Br. VII. 430 , esp. note 2, p. 431 (10 June 1536). 42. WA. 39. 1. 40-42.

43. The present writer is engaged on a study of these, the results of which should be published in a few years. For the text of the whole series of disputations see WA. 39. 1. 40-257.

44. WA. 39. 1. 44ff.

45. Ibid. $48 \mathrm{f}$.

46. Ibid. 63ff. 
exercised Luther in that they could be used in a sense as contradictory to the sola fide. He argued in the case of Daniel that Daniel is speaking of Law and Gospel, and is but pre-figuring Christ by offering Nebuchadnezzar forgiveness of sins, to accept which will issue in good works; see in particular Thesis 13. To the theses are attached important contributions in the shape of arguments and counter-arguments, to which not only the doctorands take part, Weller and Medler, but also Aepinus 47 and Barnes. In the fragment on 1 Corinthians 13 Luther argues that Paul does teach sola fide and here is arguing that without charity such faith is worth nothing.

Luther continued this theme of justification, which he had introduced in the theses de fide and de lege, in a further series of disputations, de homine and de justificatione. There are certain discrepancies in fixing the exact dates, but there is no doubt that the central subject, justification, was chosen for the benefit of the English delegates, as Melanchthon (1552) and Pezel (1600) distinctly say. 48 The 40 theses and the fragment of the disputation de homine take up the question on the basis of the much cited passage, Romans 3:28. The disputation took place on 14th January 1536. Having special significance for Luther's anthropology, the disputation is characterised by its tribute to the reason of man and his majestic position on earth. Yet, whether employed in philosophy or theology or both, reason is unable to answer the question, 'What is man?'. Luther argues that man is in bondage and can be saved only by grace. The whole disputation is a succinct argument against scholasticism, humanism and Roman catholicism and for justification by faith alone.

47. The presence of Aepinus is interesting. He was a former student of Luther and now Superintendent of Hamburg. It was he who accompanied the civic embassage of Hamburg to Henry VIII in 1534, and whom Henry requested to stay on after the deputation had left. Henry held him in high regard and hoped for his support. See the highly interesting accounts in Moenckeberg: Zeit.des Vereines für hamburgische Geschichte (1851) III. 179ff; ibid., Hans Nirrnheim: Hamburgs Gesandschaft an $K$. Heinrich VIII (1949) 26ff; ibid., Aktenstücke (1851) III. $188 \mathrm{ff}$.

48. WA. 39. 1. 79 . 
This is followed up by a third disputation de justificatione, the date of which was formerly understood to be on 14th January 1536, but now seems to have been loth October 1536. ${ }^{49}$ If this is so, the English delegates would have left Wittenberg, though they certainly heard and took part in some of the debates. Here again Luther, at the peak of his power, gives a masterly and sustained defence of the doctrine in 35 theses, and follows it up with a fourth disputation of 33 theses, which is devoted to a discussion of sin from which a man is liberated by the gracious work of Christ. There follows a preface by Luther explaining why he had the subject discussed in the university, to which are added some 40 pages of argument and counter-argument where Luther trenchantly debates all the objections against the doctrine. These pages are possibly Luther's finest discussion of the doctrine which Luther was at some pains to explain to the English.

Related to this debate is the disputation on Luke 7:47, 'Her sins are forgiven, for she loved much'. Drews dated this 2lst January 1536, for Luther raises this point as an objection to his doctrine in the third disputation, but the WA editors date it at the end of 1535. The disputation consists of 61 theses plus a Disputationsfragment, and in the argument Luther shows that Christ publicly condemned the Pharisees' judgment that according to the Law she was a sinner, by publicly declaring her liberation from the Law, saved by her faith. (See theses $37,44,50,51$.

We stand on more certain ground when we turn to the Disputatio contra missam privatam, 29th January 1536. There is clear evidence of date and time from Luther and others. 50 The English delegates, apart from the wearisome matter of the amendment, (long since settled in the minds of the Wittenberg theologians), wished to discuss four matters which Henry sought to retain: the celibacy of clergy, communion in both kinds, the popish mass, and monks' vows. Of these the decisive one was the mass. Luther saw this as the complete reversal of justification by faith. ${ }^{51}$ It is certain the English

49. Drews places it on 20 April 1536 (WA. 39. 1. 80f; WA. 39. 1. 174).

50. WA. 39. 1. 134, 137.

51. See Von der Winkelmesse (1533) (WA. 38. 7lff, 257ff). 
attended, 52 and the Wittenberg students, 53 as well as the Vice-Chancellor and the faculty, the two last-named taking part in the disputation. Burkhard's presence gave official and princely approval, obviously because Henry's ambassadors were there; the full attendance of the professors lent it theological approval.

The disputation consists of theses in syllogistic form arguing against private mass, followed by a preface from luther and arguments from him and from the participants, about 35 pages in all. All the papist arguments for the private mass are given and all refuted. The pleas that the private mass has all the elements of a pure mass and ought to be retained are made and met. The claim that an inerrant church could not be wrong on this central issue is made, and met. The theologians argue that there was no private mass in the early church, nor in the Greek Church, and that it was a fond idolatrous practice invented by priests, and of no divine authority; it was founded on the non-evangelical theology of merit earning, and provided no communion, such as Christ had intended. The evangelicals practised the rite as Christ had instituted it, and in the communion they both received Christ and strengthened faith.

Finally, there is the disputatio de potestate concilii. The historian Wilisch (1737) dates it 10th October 1536, but there is no doubt that it is closely related to the above series on justification, and further that Barnes took part. 54 We know that Barnes was in Wittenberg in March 1535, and again at the end of 1535 until loth April 1536. We know nothing of a visit in October, which raises a doubt about the accuracy of the Wilisch's dating. Further, Luther, as dean, records on 10th December 1536 the disputation of Jacobus Schenk and Philippus Motz where the Promotionsrede, given by Cruciger, was on purity of doctrine, de puritate doctrinae in Ecclesia conservanda, a theme which had nothing to do with the power of a council. Contextually the disputation belongs to the above series on justification, and for this reason, as well as the

52. WA. 39. 1. 139. 2; 166.14 .

53. Ibid. 160.17 .

54. He debated Argumenta III-IX (WA. 39. 1. 19lff). 
others, we shall treat it in this context. A delightful Doctors' Dinner took place in the Augustinian priory, now Luther's own home, for which Countess Katharina paid and the Town Council provided the drinks. (Rheinwein and cider). It was certainly a noteworthy celebration: two translations into German were published immediately, one from Iuther's arch-enemy, Colhlaeus, the other by Spalatin, now court chaplain (and formerly a fellow student of Luther at Erfurt).

Thirty decisive theses constitute the first part of the disputation, a disputation closely related to his von den Konziliis und Kirchen (1539). The argumenta of the second half discuss each thesis in turn. Luther argues that there is no authority (after Christ) that can be compared with that of the apostles and prophets, for they had the promise of the Holy Spirit and spoke with His authority and not their own; they are the foundation of the Church and have no successors. Any successor who teaches anything else is a heretic, even Antichrist. Bishops may err, and any collection of them may err. When they do not err, then the Holy Spirit has guided some holy man to speak, or group of holy men to make a stand. Luther instances Paphnutius who saved the entire Council of Nicea from error. Truth lies not with the mere assemblage as such, but with the Holy Spirit, and He cannot be put into the hands of an assembly; it is idolatrous for the Church to think they 'possess' Him in this way. Such assemblies represent the Church but do not constitute entire Christendom. No man is bound to accept such authorities, unless they speak with apostolic authority; even their own authorities say that a single man may contradict an entire council if he can offer better reasons or give scriptural authority for his views. The papists say this but do not practise it: they will not let a single Paphnutius speak. At the Nicene Council a single Paphnutius resisted the Fathers assembled; he was not burned, but praised. At the Council of Constance, 1415, two Paphnutiuses resisted, armed with Scripture; they were not praised, but burned.

Almost the entire evangelical theology was raised and argued in these disputations, ${ }^{55}$ together with many of

55. Die Promotionsdisputation von Palladius und Tilemann ( 1 June 1537?) is obviously a continuation of this series of disputations, but is not discussed here since its date is uncertain (see WA. 39. 1. 198ff). 
the prevalent abuses of the papists, and it takes little imagination to picture how impressed the Englishmen must have been. The nature of man was scrutinised, the bondage of the will shown, the inability of reason or good works to deliver him. From every angle his salvation was discussed and deliverance shown only in Christ, appropriated by justification by faith alone. Law and gospel, faith and works, the theme was probed from every approach. The nature and authority of the Church was examined, as well as the nature and purpose of true worship. The unique and sole authority of Scripture was argued, the nature and authority of creeds and councils limited. It should be recalled that these theses were drawn up by Luther himself, and argued in his own inimitable language and authority. They also carried the approval not only of his colleagues but of his prince. The conversations culminated in Melanchthon's composition of the so-called wittenberg Articles of 1536, essentially a further expression of the Confessio Augustana.

\section{The Report of the Delegates to Convocation}

The debates had concluded on 8th April, and Foxe and Heath, on their return to London, gave an account of their deliberations to Convocation, when the Ten Articles of 11th June 1536 were issued. These are unclear and evasive, and though indulgences and masses for the dead were denounced, yet there was no mention of the mass, the one thing that truly divided Catholics and protestants. After the disputations luther showed no interest in the further discussions, and left the English affair for Melanchthon to handle. He wrote to Burkhard that he was thoroughly sick of this kind of discussion which was little more than a quarrel. He had had enough with Carlstadt and Zwingli, with whom discussions led nowhere. When the English theologians said they were ready to present the Wittenberg Articles to Henry VIII, Luther wrote to his prince to the effect that if Henry approved of them then the treaty could be discussed. When John Frederick asked him whether further concessions might be made, Luther said he would make no concessions to Henry which he had refused to the Pope, but if the theology were sound, ceremonial affairs were not important, and on the basis of a sound theology Luther would leave the treaty to the princes as being a worldly affair and nothing to do with him 
as a theologian. 56

The publication of the Ten Articles in England was further implemented when Cromwell followed up with the Injunctions (1536). 57 Here he pursued reform at the level of the parochial clergy. They were to repudiate papal authority, teach the Ten Articles, remove superstitions, instruct the young, administer the sacraments, avoid intemperance and support the universities. The Ten Articles and the Injunctions kept the English busy so that no answer was conveyed to John Frederick on the results of the mission. As for Henry, the death of Catherine of Aragon and the execution of Anne Boleyn, followed by the Northern Rebellion, caused him to abandon interest in the Lutherans.

\section{Further Proceedings on English Soil}

It was the meeting of Charles $V$ and Francis $I$, and their conferences with the Pope that rekindled Henry's interest in the Lutherans. Pope Paul III had proposed a council to be held in Mantua on 23rd May, 58 and the German princes asked to be excused on the ground that no serious reform of doctrine was contemplated. They also informed Henry of their views and Henry issued a furious Protestation, explaining why he would not attend. In the meantime, owing to the unrest in the country, the Bishops'Book was published (1537), a book owing much to Lutheran influence. This was followed in 1538 by Cromwell's second Injunctions, ${ }^{59}$ which may be described as a practical application of Luther's theology. By these the Bible was to be set up in the churches, religious instruction given according to the Bible, images removed, the Word of God to be preached, erroneous teaching recanted, and registers kept. This was the background when Henry sent Christopher Mont to Germany on 25 th February 1538,60 to urge the sending of

56. W. Br. 7. 403 (20 Apr. 1536).

57. Gee and Hardy, Documents Illustrative of the History of the English Church (1896) 269-74.

58. L. \& P. XII.i. 432.

59. Gee and Hardy, 275-281.

60. L. \& P. XIII.i. 367 . 
a German delegation to England. Three delegates arrived on 3lst May: Francis Burkhardt, vice-chancellor of the Elector; George Boyneburg, a nobleman; and Frederick Mykonius, a theologian of some ability and superintendent of the church at Gotha. They brought with them a 21-page communication addressed to Henry. Cranmer presided over the meetings, and Richard Sampson (bishop of Chichester), Dr. Wilson (king's chaplain) and three other doctors represented the king. The two conservative theologians Tunstall and Stokesley were there, as were Barnes and Heath. Regrettably for the Lutheran cause, Foxe had just died, and with him Protestantism lost a learned supporter.

Discussions seemed to go well and by August the Lutherans had produced a 72-page document for Henry in which they emphasised a true communion, the abolition of the mass and of private masses, and the abolition of clerical celibacy. Henry acknowledged this with a 22page document, promising to examine these points with his divines. At the end of september the delegation returned to Germany, and Henry wrote to John Frederick in appreciation of the work of the delegation, expressing the hope that Melanchthon would come with other theologians to conclude the matter. ${ }^{61}$ Yet nothing had been achieved. Henry wanted to join the League now and discuss a league of religion afterwards. This was precisely what the Lutherans were seeking to prevent. The only tangible outcome of all the negotiations was the Thirteen Articles of 1538, yet even these were never ratified.

\section{Further Proceedings on German Soil}

Whenever there was fear in Henry's mind of the relations between Charles $\mathbf{V}$ and Francis I improving, he turned to the Lutherans. In January 1539 he sent Christopher Mont and Thomas Paynell to take up negotiations again, to include Denmark, the Palatinate and Cleves. Instructions included the exploration of religious views, and the plea for a 'notable delegation' to come to England. Mont was also to explore the possibility of the Princess Mary marrying the young Duke of Cleves, and Henry marrying the daughter of the elder Duke of

61. L. \& P. XIII.ii. 497. 
Cleves. 62 Barnes and St. Leger were sent to Denmark and to saxony to intensify the alliance.

Melanchthon, who had now virtually taken over the English affair (Luther having refused to waste his time on the affair), returned the Lutheran answer of the priority of theology over politics. The princes made the same reply, and a delegation comprising Burkhardt and and von Baumbach, Louis Bambirge and a few others arrived in London on 23rd April 1539. They interviewed the King on 29th April and Cromwell on 2nd May, in company with the Dukes of Norfolk and Suffolk, Chancellor Audley, the Admiral Earl of Southampton, and Tunstall, now Bishop of Durham. The whole matter was discussed on political grounds, the theological questions were again pushed aside. It was clear that Henry was now playing delaying tactics. The ambassadors took their leave for Germany on 31st May. ${ }^{63}$

In the meantime Barnes had carried out his mission in Denmark with great energy, and wrote back to Henry in glowing terms of the possibility of rapprochement. In May Henry learnt of the peace settlement between Charles $\mathrm{V}$ and the Lutherans, promulgated at the Diet of Frankfurt, and, under pressure (perhaps conspiracy) on the part of Gardiner and Norfolk, the king promulgated the Act for Abolishing of Diversity of Opinions (otherwise known as the Six Articles), June 1539. ${ }^{6}$ This was a reversion to the Catholic position, an effort on the part of Henry to declare his orthodoxy and avert the hostility of the Emperor, even the combined hostility of the Pope and Francis I in addition. The Diet of Frankfurt served to warn Henry that the Lutheran princes would neither take him into their League nor defend him against the Emperor. The delegation had left on 2lst May and the Lutherans were horrified to learn the news of the Six Articles, yet on his return Burkhardt wrote to Melanchthon that the enemies had

62. L. \& P. XIV.i. 103.

63. For further details of the conferences see $F$. Prueser, England und die Schmalkaldener 1535-40 (Leipzig, 1929) 169-176. For the report of Burchardt and von Baumbach see P. Singer, Beziehungen des Schmalkaldenes Bundes zu England im Jahre 1539 (Greifswald, 1901) 91-97.

64. Gee and Hardy, 303. 
succeeded in obtaining the statute, but not its execution, and that it was all a plot against cranmer and the evangelicals. 65 Bucer worked ceaselessly to restore the status quo ante, writing to wittenberg ${ }^{66}$ and to Cranmer. ${ }^{67}$ Melanchthon wrote a very long letter to Henry seeking the refutation of the Six Articles. ${ }^{68}$ The net result of this act was to close all further theological discussion with the Lutherans.

In reply to Bucer Luther said that Bucer's hopes for the King of England would be deceived; even the English delegates were more realist than he. ${ }^{69}$ Luther, Melanchthon, Bugenhagen and Jonas wrote a long letter to John Frederick giving their reasons why any further proceedlings were a hopeless enterprise. 70 Luther followed this with a private letter to John Frederick saying that the longer letter had his full approval, that Henry had revealed his duplicity and shown that it was impossible for them to have any dealings with him any longer. 71

\section{The Final Ploy - Dynastic Overtures}

If there had been little success in the theological approaches, it seemed at that time that there might be more in the dynastic approach to cleves. Anne had arrived in England on 27th December 1539. Burkhardt returned to England and had an audience with Henry on 10th January 1540. Yet, owing to the political situation in Europe, the Lutheran alliance with Cleves was beginning to look less attractive. Henry went through with the marriage on 6th June but it was dissolved on 16th July; Anne sensibly withdrew and was spared the sword; Cromwell was executed on 28th July. Two days later, on 30th July, three Protestants, Barnes, 72

65. L. \& P. XIV.ii. 423.

66. $C R$. III. 795f.

67. Hastings Robinson, Original Letters (Parker Society) II. 529.

68. A. \& M. V. $350 \mathrm{f}$.

69. W. Br. 8. $568 f$ (14 Oct. 1539).

70. W. Br. 8. 572 ff (23 oct. 1539).

71. W. Br. 8. $577 f$ (23 Oct. 1539).

72. When Luther learnt of the execution of Barnes, his friend who had sat at his own table, he published the confession which Barnes made at the stake, together with a very fine and sensitive appraisal of 
Jerome and Garret, were burnt as heretics at Smithfield, by attainder and with no charges and no trial, and at the same time and place, three Catholics, Abel, Featherstone and Powell, were hanged, drawn and quartered. Before Henry was to die, ten more Protestants and fourteen more Catholics were to meet a similar violent end.

The reason Henry retained two men so unlike as Cranmer and Gardiner must lie very simply in the fact that he needed both: Cranmer to support him at home against the papacy, Gardiner the theologically impeccable Catholic to support him in his relations with the orthodox Emperor. The last phase of Henry's foreign policy was to be his own foreign minister and seek amicable relations with Charles now that the league with the Protestants had failed. An opportunity to do this came when the Emperor called the Diet of Regensburg for 5th April 1541. Henry sent Gardiner as early as November 1540 with an impressive display of horsemen and diplomats, backed up by a huge expense account. Henry. was all along afraid that the Lutherans would be reconciled to the Catholics, and thus leave him exposed as the only king outside the spiritual domain of the papacy. The church, on the other hand, was anxious for the reconciliation on the grounds that were the Emperor to reconcile Henry to the Pope it might force the Lutheran princes into compliance. ${ }^{73}$

There was a splendid array in Regensburg: the emperor and his brother; Albrecht of Mainz; all the Protestant princes except John Frederick; Melanchthon, Bucer, Jonas, Cruciger and Alesius of the Protestants; Contarini, Eck, Faber, Gropper and von Pflug of the Catholics. The Venetian ambassador observed that the princes spent their time at banquets, while the theologians debated, but he noted what is of interest to this enquiry, that in the Catholic churches a few officials attended on Sundays while in the Protestant churches Protestant theologians preached to packed congregations daily, and could turn the whole city Protestant. ${ }^{7.4}$ The hopes of unity with Rome have never

Barnes entitled Bekantnus dess Glaubens (Wittenberg, 1540).

73. L. \& P. XVI. 870.

74. Ven. Cal. V. 257. 
been higher than they were at Regensberg. There were competent theologians on both sides (though the greatest of all, Luther, was perforce absent), and a genuine spirit of moderation prevailed. Some unanimity was found on the Augustinian doctrines of original sin and the bondage of the will. Agreement was reached even on the doctrine of justification by omitting the Lutheran sola. There was some division on the question of the power of the church, and a deadlock reached on the doctrine of the eucharist. The English Cardinal Pole was ecstatic. Yet the whole project was wrecked by the catholic insistence that a final decision rested with the Pope. It was at this time that Luther said that Rome would have to change her teaching if any real progress towards unity were to be made. Within a year of Luther's death the Emperor had actually taken up arms against the evangelical cause.

With Regensburg all hope of unity failed. When Contarini actually returned to Rome with his report he found that his influence had waned, and he died soon afterwards (1542), leaving a gap that none could fill. The Catholics who had hoped to end division by compromise and agreement now realised there was little hope. The conception of a Catholic Reformation disappeared; the idea of a Counter-Reformation took its place. The way was now clear for the Council of Trent - and the Schmalkald War.

Christopher Mont saw the dangers now that Charles and Francis were reconciled, and wrote to Henry, urging an alliance between Denmark and England, and also the renewal of talks with the Schmalkald League. ${ }^{75}$ Henry acceded, provided the political matter was settled first, the theological subsequently. ${ }^{76}$ This was Henry's former position. Philip of Hesse was anxious to renew the negotiations, John Frederick was averse. 77 Nevertheless, Baumbach and Sleidamus travelled to London, but all their efforts were fruitless owing to a complex series of political events, military escapades, French bribes and imperial threats. It was the same dismal story, again re-played.

75. L. \& P. XIX.ii. 746 .

76. L. \& P. XX.i. 91 .

77. Ibid. 212 . 
Gradually, the international pressures that had made Henry interested in Lutheranism diminished. When Regensburg had failed to bring the Catholics and Protestants together it meant exclusion of them from Trent, which ineyitably meant a war between the emperor and the Lutherans. The tragic Schmalkald war broke out in September 1546, when Lutheranism suffered military defeat and its leaders' imprisonment. Luther did not live to see this war, for he had departed this life in February 1546, but the defeat and imprisomment of the Lutheran princes closed the door to any further relations between the Lutherans and the English.

\section{Select bibliography}

The author expresses with gratitude his indebtedness to the following authors:

Doernberg, Erwin, Henry VIII and Luther (London, 1961)

Jacobs, Henry Eyster, The Lutheran Movement in England (Philadelphia, 1890)

Prueser, Friedrich, England und die Schmalkaldener 153540 (Leipzig, 1929)

Singer, Paul, Beziehungen des Schmalkaldenes Bundes zu England im Jahre 1539 (Greifswald, 1901)

Tjernagel, Neelak Serawlook, Henry VIII and the Lutherans (St. Louis, 1965) 